\title{
Developing Cultural Awareness in Foreign Language Teaching
}

\author{
Zahra Ghorbani Shemshadsara \\ Department of English, Roodbar Branch, Islamic Azad University, Iran \\ E-mail: Z.Ghorbani1971@yahoo.com
}

Received: November 1, 2011

Accepted: December 28, 2011

Published: March 1, 2012

doi:10.5539/elt.v5n3p95

URL: http://dx.doi.org/10.5539/elt.v5n3p95

\begin{abstract}
Culture awareness has become an important focus of modern language education, a shift that reflects a greater awareness of the inseparability of language and culture, and the need to prepare students for intercultural communication. The paper reports on an ongoing study into the presence and status of cultural understanding in EFL teaching. In this paper, the underlying assumptions and influences of culture awareness in Language teaching and learning critically analyzed.
\end{abstract}

Keywords: Culture awareness, Cultural sensitivity, Ethnocentrism

\section{Introduction}

The need for a strong commitment to the development of cultural understanding within the classroom context is clear in the light of recent development both nationally and internationally. Strasheim (1981) argues there is no question that the successful integration of culture and language teaching can contribute significantly to general human knowledge, that language ability and cultural sensitivity can play a vital role in the security, defense and economic well-being of the country and that global understanding ought to be a mandatory component of basic education (Stratiem 1981, cited in Hadley, 1993). Hadley (1993) asserts that cultural understanding must be promoted in various ways so that students are sensitive to other cultures prepared to live more harmoniously in the target language community. As Stern (1992) reiterates, "One of the most important aims of culture teaching is to help the learner gain an understanding of the native speaker's perspective" (p. 216) It is a matter of the L2 learner "becoming sensitive to the state of mind of individuals and groups within the target language community" (p. 217).

Wieto (2010) claims cultural sensitivity becomes little because it does little to solve deep-seated problems of inequity. She suggests that multicultural education needs to be understood as "arrogance reduction"; that is, as encompassing both individual and structural changes that squarely confront the individual biases, attitudes, and behaviors of educators, as well as the policies and practices in schools that emanate from them.

\section{Cultural Awareness}

Tomlinson (2001) holds that cultural awareness involves a gradually developing inner sense of the equality of cultures, an increased understanding of your own and other people's cultures, and a positive interest in how cultures both connect and differ (cited in Tomlinson \& Masuhara, 2004, p. 3). Tolinson and Masuhara, (2004) claim, an increased cultural awareness helps learners broaden the mind, increase tolerance and achieve cultural empathy and sensitivity. According to Tomalin and Stempleski (1993), cultural awareness encompasses three qualities:

- awareness of one's own culturally-induced behavior

- awareness of the culturally-induced behavior of others

- ability to explain one's own cultural standpoint (p.5)

Knutson (2006) points out that the development of students' cultural awareness starts by encouraging them to recognize their cultural identity in relation to other cultures. For this reason Knuston (2006) suggests teachers should analyze students' real world and academic needs in terms of cultural knowledge, awareness or ability to function in appropriate ways (Kuuston, 2006, cited in Beaudrie, et al (2009), p. 167-169). Tannen (1992) in the United States holds that cultural identity is likely to diverge based not only on learners' national and linguistic background but also on their ethnic heritage, religious beliefs, class, age, gender, and sexual orientation (Tannen, 1992, cited in Kumaravadivelu, 2003).

Woolward (1997) argues "identity gives an idea of who we are and of how we relate to others and to the world in which we live." She also claims "identity marks the way we are the same as others who share the position, and the 
ways in which we are different from those who do not" (Woolward, 1997, cited in Beaudrie, et al. (2009), pp. 167-169).

Galloway (1984) has proposed a framework for building cultural understanding based primarily on process skills, but incorporating both factual and sociolinguistic content. She suggests organizing instruction around four primary categories of understanding:

1) Convention: The goal of this type is to help students recognizes and understand how people in a given culture typically behave in common situations. Galloway identifies two types of conventions: (1) context determined conventions, which includes extralinguistic behaviors that are characteristics in a given situation and (2) function-determined conventions related to sociolinguistic formulae or conventional utterances that are used to perform tasks in context. For example if one were teaching about foods, the teacher might focus on such context-determined factors as mealtimes, types of food, conventions of etiquette as well as on appropriate expressions associated with accepting and declining invitations, making reservations at a restaurant...

2) Connotation: The category of connotation deals with the many culturally significant meanings, that are associated with words. As students examine their own networks of association they can begin to discover that the underlying meanings of words are determined by their cultural frame of reference. Galloway (1985) states certain words evoke a cluster of feeling and images. For example the word 'time' may make one nervous. At the symbolic level, it represents pressure, stress, deadlines, schedules, responsibility. Simply, a person may fear death etc.

3) Conditioning: A third category of cultural understanding has to do with the fact people act in a manner consistent with their cultural frame of reference, and all people respond in culturally conditioned ways to basic human needs to learn how to interpret behaviors that are different from their own without making judgments based on their own standards. Students need to learn how to interpret behaviors. If the students begin to expect cultural differences as natural and inevitable and realize that there are indeed a variety of possible differences to the universal need for food, shelter, social contact, and the like, they may begin to view the other culture more emphatically.

4) Comprehension: This category of cultural understanding includes such skills as analysis, hypothesis formation, and tolerance of ambiguity. According to Galloway (1985), comprehension goals can best be achieved by paying attention to the source of one's information, examining one's stereotypes avoiding overgeneralization, and the ways to resolve conflicts.

Ho (2009) claims still, the development of the cultural awareness in English language classes may be influenced by a number of constraints, namely the teacher's cultural knowledge, the availability of native English speakers, time allowance for culture teaching in each lesson or even the system of education itself. The teacher has been considered the expert knower of the language (Kramsch \& Sullivan, 1996) and his/her own cultural knowledge thus seems to be the main source for students to learn about. However, this role of the teacher has been diminished (Kramsch \& Sullivan (1996, Ho, 2009, p. 63-76). With the booming of information technology and the effects of globalization that make many countries dependent on each other, students are now able to get access to many cultural resources and explore the target culture themselves. The availability of native English speakers as a rich cultural resource is also an important issue for consideration. Time allowance for culture teaching is also a big issue for teachers as lessons are already very loaded. In spite of that, if teachers know how to incorporate language and culture in language teaching in a flexible way, they can solve the problem easily and even make their lessons more interesting (Ho, 2009, p. 63-76).

\section{Culture Teaching}

Kumaravadivelu (2003) holds that culture teaching played a subterranean role in most L2 education. It became part of what Michael Byram (1989) has called 'the hidden curriculum,' indirectly seeing to create in the learner empathy toward and an appreciation for the culture of the target language community (cited in Kumavadavilu, 2001, p. 268). According to a more recent review by Stern (1992), culture teaching has generally included a cognitive component, an affective component and a behavioral component. The cognitive component relates to various forms of knowledge - geographical knowledge, knowledge about the contributions of the target culture to world civilization, and knowledge about differences in the way of life as well as understanding of values and attitudes in the L2 community. The affective component relates to L2 learners' curiosity about and empathy for the target culture. The behavioral component relates to learners' ability to interpret culturally relevant behavior, and to conduct themselves in culturally appropriate ways.

Kumaravadivelu (2003) holds what the traditional approach to the teaching of culture ignores is the rich diversity of world views that learners bring with them to the language classroom. That is, even if a group of learners appear to belong to a seemingly homogeneous national or linguistic entity, their life values, life choices, life-styles, and, 
therefore their world view may significantly vary. In that sense, most classes, according to Kumaravadivelu, are not monocultural cocoons but rather are multicultural mosaics.

Robinson (1985) was one of the first in the field of L2 education to argue that instead of treating culture as a collection of static products or facts that may be presented to learners in discrete items, it should be viewed as a process, that is, as a way of perceiving, interpreting, feeling, understanding. This perspective views culture as part of the process of living and being in the world, the part that is necessary for making and understanding meaning. Robinson (1985) talks what she calls 'cultural versatility,' which implies "expanding one's repertoire of experiences and behaviors, not subtracting anything" (p. 101). When people expand their cultural repertoire, they "would become a little bit of 'other,' and would have a degree of psychological match with more people" (p. 101)

The idea of culturally shared meaning has been further elaborated by Kramsch in 1993. She sees culture both as facts and as meanings, and she sees the L2 classroom as a site of struggle between the learners' meanings and those of native speakers. Through this struggle, L2 learners create their own personal meanings at the boundaries between the native speakers' meanings and their own everyday life. She asserts that "from the clash between the familiar meanings of the native culture and the unexpected meanings of the target culture, meanings that were taken for granted are suddenly questioned, challenged, problematized" (p. 238). To sum up, Kramsch (1993) would like teachers and learners to create what she calls "a third culture" in the L2 classroom. She describes the third culture as a conceptual space that recognizes the L2 classroom as the site of intersection of multiple world of discourse. She advises teachers to encourage learners to create this third culture while, at the same time, not allowing either the home culture or the target culture to hold them hostage to its particular values and beliefs. She further adds the true understanding of the cultural dynamics of the L2 classroom can emerge only through an understanding of the cultural identity that teachers and learners bring with them. Such an understanding is possible only if teachers and learners develop what Kumaravadavilu calls critical cultural consciousness. The development of critical cultural consciousness requires the recognition of a simple truth: there is no one culture that embodies all and only the best human experience; furthermore, there is no one culture that embodies all and only the worst of human experience.

\section{Culture Conflict}

Levine and Adelman (1982) maintain cultural conflicts occur as a result of misinterpretations, ethnocentrism, stereotypes, and prejudice. Preventing these conflicts is possible with increased awareness of our own attitudes as well as sensitivity to cross-cultural differences. Developing cultural sensitivity does not mean that we need to lose our cultural identities - but rather that we recognize cultural influences.

Patrikis (1988) recognizes the dangers of ethnocentricism (based on the ideas and beliefs of one particular culture and using these to judge other cultures) and bias in the presentation of cultural materials, and warns about several sins of commission that can occur in discussion of culture. The first of these is stereotyping, which consists of exaggerating some aspects or characteristics of a culture or its people. Patrikis affirms that we must learn to distinguish between types (common traits) and stereotypes (fixed images) to teach our students to identify types and stereotypes and to recognize the limitations of the type. The second sin is that of triviality, which consists of reducing the dizzying variety of cultural elements to the silly, the out of date, or the quaint, thus presenting tokens of a culture divorced from the meaning of their context. The third sin is that of political bias, which can result either consciously or unconsciously when we select elements of the culture to feature or include while ignoring others. Related to this problem is the fourth sin of dangerous incompleteness which consists of leaving a whole subculture or other crucial part of culture out of the discussion. A course, for instance, on the Middle East that focuses only on Islamic culture, and leaves out consideration of Jews, Christians, and other minorities to the sin of dangerous incompleteness.

Liddicoat (2002) mentions that there are generally two views toward culture awareness: the static versus the dynamic. The static view of culture does not recognize the link between language and culture. It merely transmits cultural information to learners and ignores the constantly developing nature of culture. On the contrast, the dynamic view of culture requires learners to actively engage in culture learning, rather than only learn about the cultural information of the target culture in a passive way. They are encouraged to view cultural facts as situated in time and space and variable across time, regions, classes and generations. The dynamic view of culture also requires learners to have knowledge of their own culture and an understanding of their own culturally-shaped behaviors. Weaver's (1993) cultural iceberg shows that a large proportion of our own culturally-shaped knowledge is invisible and mostly subconsciously applied in our everyday interactions (cited in Kiet Ho, 2009, p. 63-76).

Morgan et al (1994) hold that it is only in the 1980s that scholars begin to delve into the dynamics of culture and its vital contribution to successful language learning. (cited in Thanasoulas, 2001). More specifically, when the learner understands the perspectives of others and is offered the opportunity to reflect upon his own perspectives, through a 
process of decentering and a level of reciprocity, there arises a moral dimension, a judgmental tendency which is not defined purely on formal, logical grounds. To this end the learner needs to take the role of a foreigner so that he gains insights into the values and meanings that the latter has internalized and unconsciously negotiates with the members of the society to which he belongs. Kramsch (1993) also believes that culture should be taught as interpersonal processes and rather than presenting cultural facts, teachers should assist in coming to grips with the other cultures. She maintains that by virtue of increasing multiculturality of various societies, learners should be made aware of certain cultural factors at work, such as age, gender, social class provided that the former usually have little or no systematic knowledge about their membership in a given society and culture, nor do they have enough knowledge about the target culture to be able to interpret and synthesize the cultural phenomena presented (Kramsch, 1988). The corollary of this perspective is to view the teaching of culture as a means of developing an awareness of, and sensitivity towards, the values and traditions of the people whose language is being studied.

\section{Implications for Language Teachers}

To Leveridge (2008), language teachers must instruct their students on the cultural background of language usage, choose culturally appropriate teaching styles and explore culturally based linguistic differences to promote understanding instead of misconceptions or prejudices. The students, when using the learnt language, may use the language inappropriately or within the wrong cultural context, thus defeating the purpose of learning a language.

Because language is closely entwined with culture, language teachers entering a different culture must respect their cultural values. As Englebert (2004) describes: “... to teach a foreign language is also to teach a foreign culture, and it is important to teach a foreign culture, and it is important to be sensitive to the fact that our students, our colleges, our administrators, and, if we live abroad, our neighbors do not share all of our cultural paradigms (cited in Leveridge, 2008, p. 100).

Language teachers must realize that their understanding of something is prone to interpretation. The meaning is bound in cultural context. One must explain the meaning of the language used, but the cultural context in which it is placed as well. Often meanings are lost because of cultural boundaries which do not allow such ideas to persist. Porter (1987) argues that misunderstandings between language educators often evolve because of such differing cultural roots, ideologies, and cultural boundaries which limit expression. As Hui (2005) puts forth language teachers must remember that people from different cultures learn things in different ways. For example, in China memorization is the most pronounced way to study a language which is very unlike western ideologies where the onus is placed of free speech as a tool for utilizing and remembering vocabulary and grammar sequences. Maley (1986) asserts that when a teacher introduces language teaching materials, such as books and handouts, they must understand that these will be viewed differently by students depending on their cultural views. In fact, one should not only compare but also contrast the cultural differences in language usage. Visualizing and understanding the differences between the two will enable the student to correctly judge the appropriate uses language idiocyncracies. (Leveridge, 2008). Valdes (1987) argues that not only similarities and contrasts in the native and target languages have been useful in as teaching tools, but when the teacher understands cultural similarities and contrasts, and applies that knowledge to teaching practices, they too become advantageous learning tools.

\section{Conclusion}

A shift from a traditional to intercultural stance in EFL enhances students' awareness of the inextricable and interdependent relationship between language and culture and teaching culture as an integral component of language teaching. It also helps to develop teachers' intercultural perspectives that may have an impact on their language teaching methodology and syllabus design. This shift is a challenge that EFL teachers and learners have to deal with to meet the goals of foreign language education in our modern world.

\section{References}

Beaudrie, S., Ducar, C., \& Relano-Pastor, A. M. (2009). Curricular perspective in the heritage language teaching: Assessing, culture and identity. Language, Culture and Curriculum, 22(2), 157-174. http://dx.doi.org/10.1080/07908310903067628

Bram, M., \& Morgan, C. (1994). Teaching and Learning Language and Culture. Great Britain: WBC.

Englebert, J. (2004). Character or culture? EFL Journal, 24(2), 37-41

Galloway, V. B. (1984). Communicating in a cultural context. ACTFL Master Lecture Series. Monterey, CA: Defense Language Institute.

Ha. P. L. (2007). Australian trained teachers of English culture and identity formation. Language, Culture and Curriculum, 20(1), 20-35. http://dx.doi.org/10.2167/lec324.0 
Hadley, A. O. (1993). Teaching language in context. Boston: Heinle and Heinle Publishers.

Ho, S. T. K. (1999). Addressing culture in EFL classroom: The challenge of shifting from a traditional to an intercultural stance. Electronic Journal of foreign Language Teaching, 6(1), 63-76

Hui, D. (2005). False alarm or real warning? Implications for China of teaching. English Journal of Educational Enquiry, 6(1), 90-109

Kim, J. (2004). Coping with cultural obstacles to speaking English in the Korean secondary school context. Asian EFL Journal, 6(3). [Online] Available: http://www.asian.efl-journal (May 2011)

Kramsch, C. (1993). Context and culture in language teaching. Oxford: Oxford University Press.

Kramsch, C., \& Sullivan, P. (1996). Appropriate pedagogy. ELT Journal, 50(3), 199-212. http://dx.doi.org/10.1093/elt/50.3.199

Kumaravadivelu, B. (2003). Beyond method: Macrostrategies for language teaching. London: Yale University press.

Leveridge, A. N. (2008). The relationship between language and culture and the implications for language teaching. [Online] Available: http://www.tefl.net (October 2011)

Levine, D. R., \& Adelman, M. B. (1982). Beyond language: Intercultural communication for English as a second language. New Jersey: Prentice Hall Regents.

Liddicoat, A. J. (2002). Static and dynamic views of culture and intercultural language acquisition. Babel, 36(3), 4-11

Maley, A. (1986). A miracle of rare device: the teaching of English in China. In J.M. Valdes (Ed.), Culture bound: bridging the cultural gap in language teaching (pp. 102-111). Cambridge: Cambridge University Press.

Neito, S. (2010). Language, Culture, and teaching: A critical perspective. New York: Routledge.

Porter, E. (1987). Foreign involvement in China's colleges and universities: a historical perspective. International Journal of Intercultural Relations, 11(4), 369-385. http://dx.doi.org/10.1016/S0147-1767(87)80004-4

Robinson, G. L. (1985). Cross cultural understanding processes and approaches for foreign language, English as a foreign language and bilingual educators. New York and Oxford: Pergamon.

Stern, H. H. (1992). Issues and options in language teaching. Oxford University Press.

Thamasoulas, D. (2001). The importance of teaching culture in foreign language classroom. [Online] Available: http://www.Radicalpedagogy (October 2011)

Tomalin, B., \& Stempleski, S. (1993). Cultural awareness. Oxford: Oxford University Press.

Tomlinson, B., \& Musuhara, H. (2004). Developing cultural awareness. MET, 13(1), 1-7

Valdes, J. M. (1987). Culture Bound: Bridging the Cultural Gap in Language Teaching. Cambridge: Cambridge University Press. 